\title{
PENGEMBANGAN EKONOMI LOKAL SEBAGAI ALTERNATIF PROGRAM PEMBERDAYAAN
}

\author{
Oleh: \\ Yesi Fitriani, Santoso T, Raharjo \& Hery Wibowo \\ Email : \\ (yesifitriani39@gmail.com; hery_fortune@yahoo.com)
}

\begin{abstract}
ABSTRAK
Ide utama pemberdayaan bersentuhan dengan konsep mengenai kekuasaan. Pemberdayaan menunjuk pada kemampuan orang, khususnya kelompok rentan dan lemah sehingga mereka memiliki kekuatan atau kemampuan. Paparan singkat ini bertujuan untuk memberikan gagasan mengenai program-program pemberdayaan baik oleh pemerintah maupun swasta. Ditengah gencarnya pelaksanaan program pemberdayaan masyarakat, meskipun berbagai prestasi yang telah dicapai tetapi di sisilain masih terdapat banyak catatan buruk mengenai implementasi dan hasil dari pelaksanaan program pemberdayaan masyarakat.

Dapat dilihat dari beberapa program pemberdayaan yang dijalankan selama ini, terutama oleh pemerintah pusat. Betapa banyak program pemberdayaan yang dijalankan namun berakhir dengan kegagalan. Atau pada kondisi lain, misi pemberdayaan yang diemban program-program tersebut justru bermuara pada semakin tidak berdayanya kelompok masyarakat yang seharusnya diberdayakan.

Berpijak pada perspektif pembangunan kesejahteraan sosial, bahwa membangun dan memberdayakan masyarakat memerlukan pendekatan holistik yang mempertimbangkan isu-isu lokal dan global. Hal ini dilakukan agar program pemberdayaan masyarakat dapat berkelanjutan.

Kata kunci : Pembangunan kesejahteraan sosial, Pemberdayaan, Program
\end{abstract}

\section{Pendahuluan}

Pembangunan masyarakat seringkali memakai istilah pemberdayaan masyarakat, karena dalam perkembangannya istilah pemberdayaan ini telah menjadi wacana (discourse) publik dan bahkan seringkali dijadikan kata kunci (key word) bagi kemajuan dan keberhasilan pembangunan masyarakat (Huraerah, 2011: 95). Hal tersebut sejalan dan dapat dibuktikan dengan banyaknya program-program pemerintah yang bertemakan pemberdayaan, mulai dari program Inpres Desa Tertinggal (1994-1998), Program Kesejahteraan Sosial Kelompok Usaha Bersama Keluarga Muda Mandiri (Prokesos KUBE KMM), Tabungan Kesejahteraan Rakyat (Takesra), Kredit Usaha Kesejahteraan Rakyat (Kukesra), Kredit Usaha Kecil Menengah, Jaring Pengaman Sosial (JPS), P2KP, Bantuan Langsung Tunai (BLT), Program Nasional Pemberdayaan Masyarakat Mandiri (PNPM) dan sebagainya.

Namun pada kenyataannya meskipun sedang gencar-gencarnya pelaksanaan program pemberdayaan masyarakat, pada pelaksanaannya program pemberdayaan kini tengah kehilangan makna pemberdayaan sebenarnya. Dapat kita rasakan sendiri program pemberdayaan yang bertujuan untuk menyelesaikan masalah, justru membuat masalah sosial baru. Serta pada pelaksanaannya masih banyak memiliki kekurangan, hal ini sejalan dengan pendapat oleh Ife, (1996:56)

“..., pemberdayaan menjadi "trademark" atapun jargon yang dapat dicontohkan pada agenda dan kegiatan apa saja. Kondisi ini, dalam batas-batas tertentu, telah menyebabkan 
reduksi makna pemberdayaan sekaligus membelokkan pemberdayaan dari orientasi awalnya. Dengan kata lain, pemberdayaan telah semakin kehilangan makna substantifnya bersamaan digunakannya konsep tersebut untuk berbagai situasi dan kondisi."

Seperti yang diungkapkan di muka, bahwa banyak sekali program pemberdayaan yang menuai kegagalan. Serta banyak kelompok target yang menjadi sasaran pemberdayaan justru menjadi korban dari program pemberdayaan itu sendiri. Satu-satunya program pemberdayaan yang cukup sukses dalam mengetaskan kemiskinan adalah Program Inpres Desa Tertinggal (IDT), yang digulirkan pada masa Soeharto. Program tersebut mampu menjadikan Indonesia sebagai salah satu negara yang berhasil menanggulangi kemiskinan, karena terjadi peningkatan $20 \%$ saat itu. Namun, ketika tahun 1997 Indonesia mengalami krisis keuangan, jumlah orang miskin yang tadinya terkurangi secara drastis meninggi lagi.

Contoh lainnya seperti pada program BLT, program Bantuan Langsung Tunai (BLT) atau disebut juga dengan Subsidi Langsung Tunai (SLT) merupakan program pemerintah yang bertujuan sebagai kompensasi atas kenaikan harga BBM sejak tahun 2005 lalu. BLT ini disalurkan secara langsung dan tunai diberikan melalui cabang-cabang PT. Pos Indonesia, dengan alokasi anggaran untuk setiap rumah tangga miskin mendapatkan jatah Rp. 100.000,- /bulan dan dibayarkan setiap tiga bulan sekali.

Pada pelaksanaannya program BLT ini cukup menuai kontropersi, karena bahwasanya pelaksanaan program BLT ini memiliki catatan-catatan buruk. Seperti, banyaknya penerima bantuan yang bukan penyandang masyarakat golongan tidak mampu atau miskin (tidak tepat sasaran), penerima bantuan tidak sepenuhnya menerima uang dengan jumlah sebenarnya hal ini terjadi karena ada sistem yang dibuat oleh masyarakat. Dengan beralasan masih banyaknya Kepala Keluarga yang tidak mampu, belum terdaftar menjadi penerima program maka penerima program yang telah terdaftar harus memotong uang bantuan sebagian untuk diberikan kepada Keluarga miskin yang lain. Fenomena ini memperjelas bahwa tidak efektifnya program BLT ini, selain permasalahan yang terjadi pada pelaksanaannya yang dampak yang terpenting perlu di fahami adalah bahwa program ini menimbulkan efek ketergantungan pada masyarakat.

Hal serupa terjadi pada program PNPM, program PNPM Mandiri adalah program nasional dalam wujud kerangka kebijakan sebagai dasar dan acuan pelaksanaan program-program penanggulangan kemiskinan berbasis pemberdayaan masyarakat. Program ini bertujuan untuk memberdayakan masyarakat miskin dengan melibatkan semua komponen masyarakat (pemerintah, swasta, dan masyarakat) dengan menerapkan konsep pembangunan partisipatif secara konsisten, dinamis dan berkelanjutan. Jika melihat pedoman pelaksanaan program ini, rangkaian pemberdayaan meliputi capacity building masyarakat. Dimana dalam kegiatan tersebut menekankan pada proses pendampingan melalui fasilitator, mediasi, pengembangan kapasitas, dimana relawan adalah aktor utama penggerak masyarakat. Selain itu, penyediaan dana bagi masyarakat untuk membiayai kegiatan-kegiatan dalam rangka meningkatkan kesejahteraan rakyat miskin. Serta tidak ketinggalan adalah penyediaan sarana dan prasarana fisik, sosial, ekonomi secara padat karya.

Meskipun program berbasis masyarakat, program PNPM Mandiri belum cukup memperlihatkan pencapaian yang berhasil memberdayakan masyarakat. Pada pelaksanaannya yang terjadi dilapangan, diantaranya masyarakat membuat program yang akan dilaksanakan diwilayahnya hanya berorientasi pada masalah pembangunan fisik seperti sarana prasarana umum (perbaikan jalan, pembangunan sekolah). Bukan dalam arti perbaikan secara fisik tidak penting, akan tetapi kapasitas masyarakat turut serta penting menjadi ukuran keberhasilan pemberdayaan.

Lalu apa yang salah pada program-program pemberdayaan masyarakat selama ini, sehingga permasalahan masyarakat tidak kunjung selesai meskipun dengan telah banyaknya pelaksanaan program pemberdayaan masyarakat. Maka hal yang perlu dilakukan adalah meninjau lebih dalam terkait dengan program pemberdayaan masyarakat apakah program yang dilaksanakan telah 
memberdayakan apa sebaliknya, serta perlu adanya peninjauan ulang mengenai makna pemberdayaan itu sendiri.

\section{Pembahasan}

Pemberdayaan masyarakat kini mengalami penyempitan makna, dapat terlihat dari dominannya program-program pengembangan masyarakat (community development) yang bermatra usaha ekonomi produktif berskala mikro, seperti "warungisasi" (setiap kelompok sasaran atau warga binaan dilatih atau diberi modal agar dapat membuka warung) atau "kambingisasi" (pemberian kambing kepada kelompok miskin untuk dikelola secara kelompok) (Suharto, 2005).

Pendapat diatas menjelaskan bahwa, kegiatan pemberdayaan selama ini hanya berorientasi lokal. Memang tidak ada yang salah dengan pendekatan secara lokal. Hanya saja tanpa dengan adanya perspektif holistik (luas) yang memadukan kegiatan-kegiatan lokal dengan analisis kelembagaan dan kebijakan sosial secara terintegrasi, pendekatan tidak akan berkelanjutan.

Pendekatan secara holistik ini merupakan pendekatan dengan melihat aspek yang mempengaruhi secara keseluruhan (sistem sosial secara luas), misalnya mengenai pembangunan sosial, kebijakan sosial dan sistem sosial lainnya yang ada dalam masyarakat apakah telah mendukung dalam keberlangsungan program pemberdayaan masyarkat atau malah sebaliknya.

Secara konseptual, pemberdayaan atau pemberkuasaan (empowerment), berasal dari kata 'power' (kekuasaan atau keberdayaan). Karenanya, ide utama pemberdayaan bersentuhan dengan konsep mengenai kekuasaan. Pemberdayaan menunjuk pada kemampuan orang, khususnya kelompok rentan dan lemah sehingga mereka memiliki kekuatan atau kemampuan dalam (a) memenuhi kebutuhan dasarnya sehingga mereka memiliki kebebasan (freedom), dalam arti bukan saja bebas mengeluarkan pendapat, melainkan bebas dari kelaparan, bebas dari kebodohan, bebas dari kesakitan, (b) menjangkau sumber-sumber produktif yang memungkinkan mereka dapat meningkatkan pendapatannya dan memperoleh barang-barang dan jasa-jasa yang mereka perlukan dan (c) berpartisipasi dalam proses pembangunan dan keputusan-keputusan yang mempengaruhi mereka (Suharto, 2005).

Dengan demikian, pemberdayaan adalah sebagai proses dan tujuan. Sebagai proses, pemberdayaan adalah serangkaian kegiatan untuk memperkuat kekuasaan atau keberdayaan kelompok lemah dalam masyarakat, termasuk individu-individu yang mengalami masalah kemiskinan. Sedangkan, sebagai tujuan maka pemberdayaan merujuk pada keadaan atau hasil yang ingin dicapai oleh sebuah perubahan sosial yaitu masyarakat yang berdaya, memiliki kekuasaan atau mempunyai pengetahuan dan kemampuan dalam memenuhi kebutuhan hidupnya baik yang bersifat fisik, ekonomi, maupun sosial seperti memiliki kepercayaan diri, mampu menyampaikan aspirasi, mempunyai mata pencaharian, berpartisipasi dalam kegiatan sosial, dan mandiri dalam melaksanakan tugas-tugas kehidupannya.

Mengenai pemberdayaan sejatinya memiliki makna dan aktifitas tersendiri yang bertujuan untuk memperoleh kondisi yang diharapkan, hal ini dikemukakan oleh Wilson (Sumaryadi, 2004) bahwa kegiatan pemberdayaan pada setiap individu dalam suatu organisasi merupakan suatu siklus kegiatan yang terdiri atas:

1. Menumbuhkan keinginan pada diri seseorang untuk berubah dan memperbaiki, yang merupakan titik awal perlunya pemberdayaan. Tanpa adanya keinginan untuk berubah dan memperbaiki maka semua upaya pemberdayaan masyarakat yang dilakukan tidak akan memperoleh perhatian, simpati, atau patisipasi masyarakat.

2. Menumbuhkan kemauan dan keberanian untuk melepaskan diri dari kesenangan dan atau hambatan-hambatan yang dirasakan, untuk kemudian mengambil keputusan mengikuti pemberdayaan demi terwujudnya perubahan dan perbaikan yang diharapkan.

3. Mengembangkan kemauan untuk mengikuti atau mengambil bagian dalam kegiatan pemberdayaan yang memberikan manfaat atau perbaikan keadaan. 
4. Peningkatan peran atau partisipasi dalam kegiatan pemberdayaan yang telah dirasakan manfaat / perbaikannya.

5. Peningkatan peran dan kesetiaan pada kegiatan pemberdayaan, yang ditunjukkan berkembangnya motivasi-motivasi untuk melakukan perubahan.

6. Peningkatan efektivitas dan efisiensi kegiatan pemberdayaan.

7. Peningkatan kompetensi untuk melakukan perubahan melalui kegiatan pemberdayaan baru.

Untuk mengetahui fokus dan tujuan pemberdayaan secara operasional, maka perlu diketahui berbagai indikator keberdayaan yang tepat menunjukkan seseorang atau kelompok itu berdaya atau tidak. Keberhasilan pemberdayaan masyarakat dapat dilihat dari keberdayaan mereka menyangkut kemampuan ekonomi, kemampuan mengakses manfaat kesejahteraan, dan kemampuan kultural dan politis. Maka yang menjadi pertanyaan besar adalah, sudahkah program pemberdayaan masyarakat yang telah dilkukan selama ini berhasil membuat kelompok rentan atau tidak berdaya memiliki kekuasaan atau mempunyai pengetahuan dan kemampuan dalam memenuhi kebutuhan hidupnya baik yang bersifat fisik, ekonomi, maupun sosial seperti yang sudah disebutkan tadi dalam indikator pemberdayaan?

Maka jawabannya dapat kita lihat sendiri bahwa pemberdayaan masyarakat yang telah dilaksanakan oleh pihak pemerintah terutama ataupun swasta, program yang digulirkan belum menunjukkan keberhasilan yang signifikan meskipun tidak semua pemberdayaan yang berakhir kegagalan.

Terpusatnya perhatian pada upaya pemberdayaan masyarakat, terutama untuk golongan yang kurang beruntung (powerless), merupakan cara pandang simplistik yang berusaha mengeliminasi persoalan ketidakberdayaan pada kelompok masyarakat. Sementara realitas ketidak berdayaan pada dua pilar good governance lainnya masih agak luput dari perhatian. Hal itu menjadi salah satu penyebab, bahkan penyebab utama, gagalnya program-program pemberdayaan selama ini adalah masih kuatnya peran negara, dan oleh karenanya, sangat bias kepentingan negara yang antara lain dapat dilihat dari model pendekatan yang digunakan (Fakih, 1996 dalam artikel KPEL).

Selain itu, kegagalan kebijakan-kebijakan pemberdayaan juga disebabkan oleh tidak adanya pendekatan yang baik dan integral yang mampu menjamin sustainabilitas program. Hal tersebut telah disinggung sebelumnya, bahwa kegagalan program pemberdayaan juga dapat disebabkan karena tidak memperhatikan aspek sistem sosial yang lebih luas. Justru dengan sistem sosial ini berpengaruh terhadap keberlangsungan program pemberdayaan, sejalan dengan pendapat tersebut Rubin, 1986 berpendapat bahwa

“..., kelembagaan merupakan salah satu jalan keluar yang menjanjikan “.

Kelembagaan disini merupakan salah satu sistem sosial yang mendukung dan berpengaruh terhadap keberlangsungan program pemberdayaan. Dengan berbagai karakter inherennya, pendekatan ini mampu menjamin sustainabilitas kebijakan apapun yang sedang dijalankan sejauh diintroduksi secara konsisten. Tuntutan ini sekaligus menjadi salah satu titik terlemah dalam berbagai program pemberdayaan yang dijalankan selama ini.

\section{Kesimpulan}

Berdasarkan penjelasan di atas mengenai konsep pemberdayaan, dan beberapa implementasi beberapa program pemberdayaan. Maka penulis berkesimpulan, bahwa pelaksanaan programprogram pemberdayaan masyarakat masih belum optimal dan terjadi banyak kekurangan serta pada program pemberdayaan telah kehilangan makna pemberdayaan sebenarnya. Berikut point alasan kenapa program pemberdayaan selalu berakhir pada kegagalan,

- Program pemberdayaan masih banyak bersifat karikatif 
Pemberian bantuan-bantuan sosial yang bersifat karikatif memang perlu, asalkan tidak dijalankan secara terus menerus, karena hal ini menimbulkan ketergantungan masyarakat kepada pemerintah. Akibatnya, masyarakat tidak bisa memberdayakan diri secara mandiri. Seperti misalnya program BLT, pemberian bantuan ini masih sebatas memenuhi basic needs masyarakat.

- Kebijakan program tidak disertai dengan manajemen yang baik

Seperti halnya penyaluran program Raskin dan BLT tidak tepat sasaran, akibat dari data penduduk yang tidak valid yang dipakai pemerintah. Contohnya orang sudah meninggal dicatat sebagai penerima bantuan ataupun keluarga yang mampu secara ekomonomi pun juga menerima.

- Program pemberdayaan masih bersifat tidak berkelanjutan, disebabkan program yang dibuat tidak serta didukung dengan sistesm sosial yang mempengaruhi berjalannya program.

- Tidak banyak program yang dibuat secara partisipasi, dalam arti partisipasi disini adalah masyarakat ikut serta dalam pembuatan program.

\section{Saran}

Salah satu aternatif untuk program pemberdayaan di bidang ekonomi adalah pengembangan ekonomi lokal, sebetulnya program dibidang ekonomi ini telah dilakukan oleh beberapa pihak pemerintah maupun swasta. Namun, program

pengembangan ekonomi lokal ini masih belum banyak dilakukan dan bahkan belum optimal.

Pengembangan Ekonomi Lokal (PEL) merupakan proses di mana pemerintah lokal dan organsisasi masyarakat terlibat untuk mendorong, merangsang, memelihara, aktivitas usaha untuk menciptakan lapangan pekerjaan.

Dari sisi masyarakat, Pengembangan Ekonomi Lokal diartikan sebagai upaya untuk membebaskan masyarakat dari semua keterbatasan yang menghambat usahanya guna membangun kesejahteraannya. Kesejahteraan tersebut dapat diartikan secara khusus sebagai jaminan keselamatan bagi adat istiadat dan agamanya, bagi usahanya, dan bagi harga dirinya sebagai manusia. Semua jaminan tersebut tidak dapat diperoleh dari luar sistem masyarakat karena tidak berkelanjutan, dan oleh karena itu harus diupayakan dari sistem masarakat itu sendiri yang kerap kali disebut kemandirian. Dengan demikian, pembangunan ekonomi lokal merupakan upaya pemberdayaan masyarakat ekonomi dalam suatu wilayah dengan bertumpukan kepada kekuatan lokal, baik itu kekuatan nilai lokasi, sumber daya alam, sumber daya manusia, teknologi, kemampuan manajemen kelembagaan (capacity of institutions) maupun asset pengalaman (Haeruman, 2001 dalam artikel KPEL).

Pengembangan ekonomi lokal erat kaitannya dengan pemberdayaan sumberdaya manusianya, lembaganya dan lingkungan sekitarnya. Untuk mengembangkan ekonomi lokal tidak cukup hanya dengan meningkatkan kemampuan sumberdaya manusianya, tetapi juga diperlukan adanya lembaga yang terlatih untuk mengelola sumberdaya manusia yang sudah maju, dan memerlukan lingkungan yang kondusif untuk memungkinkan lembaga ekonomi lokal tersebut berkembang.

Maka jika dilihat program pemberdayaan melalui dengan pengembangan ekonomi lokal, serta didukung dengan sumber daya alam, sumber daya manusia, teknologi, kemampuan manajemen kelembagaan (capacity of institutions) akan membuat program pemberdayaan cukup berhasil.

Adapun untuk masa-masa yang akan datang, upaya pemberdayaan dalam hal apapun harus terlebih dahulu menjawab beberapa pertanyaan fundamental berikut:

Pertama, siapa atau kelompok mana yang harus diberdayakan? Pertanyaan tersebut akan mengarahkan pada upaya identifikasi secara obyektif dan relatif komprehensif aktor-aktor mana yang menentukan masa depan pembangunan, tetapi mengalami banyak keterbatasan, dan oleh karenaya, harus dijadikan sasaran pemberdayaan. Dalam konteks pemberdayaan ekonomi lokal, pertanyaan tersebut akan mengarah pada economic cluster yang semakin spesifik seperti kelompok petani, 
nelayan, pengusaha kecil, pedagang eceran, dan sebagainya. Identifikasi semacam itu sangat penting sehingga nantinya dapat ditetapkakn strategi yang tepat dalam sebuah konteks yang spesifik. Sebaliknya, identifikasi yang kabur dan cenderung bias akan berakibat pada kesalahan menentukan kelompok sasaran serta strategi implementasinya. Muaranya adalah, lagi-lagi, terjadinya kegagalan dalam upaya pemberdayaan.

Kedua, dalam hal apa kelompok-kelompok yang telah diidentifikasi tadi harus diberdayakan? Atau singkatnya, apa yang mau diberdayakan? Pertanyaan tersebut berkaitan erat dengan persoalan fundamental apa yang benar-benar dialami suatu kelompok. Dikatakan fundamental apa yang benarbenar sedang dialami suatu kelompok. Dikatakan fundamental karena persoalan tersebut berhubungan langsung dengan kemampuan dan akses mereka dalam upaya meningkatkan taraf hidup dan derajat keberdayaannya. Pada tataran yang lebih riil, pertanyaan tersebut akan berhubungan dengan pilihan hidup seseorang atau suatu kelompok, proses definisi kebutuhan untuk mewujudkan pilihan tersebut, bagaimana pengembangan gagasan, bagaimana mengembangkan institusi atau organisasi pendukung, sumberdaya apa yang paling dibutuhkan, apa aktivitas-aktivitas ekonomi pokoknya, bagaimana sistem produksi, dan sebagainya. Dengan demikian, upaya pemberdayaan tidak saja memiliki objek yang jelas tetapi juga fokus yang spesifik.

Ketiga, bagaimana atau dengan cara apa pemberdayaan dilakukan? pertanyaan tersebut berkaitan dengan strategi yang akan ditempuh untuk mengupayakan pemberdayaan. Pertanyaan itu sangat mendasar, dan karenanya, harus dijawab dengan tepat sehingga upaya implementasi programprogram pemberdayaan dapat mencapai tujuan dan sasaran yang diinginkan. Sebaliknya, pilihan strategi yang keliru akan berakibat pada gagalnya misi pemberdayaan yang diemban suatu program atau kebijakan. Atau lebih buruk lagi, program pemberdayaan yang coba diintroduksi untuk memperbaiki nasib target group itu tidak memberikan solusi apa-apa, tetapi malah menciptakan masalah baru.

\section{Daftar Pustaka}

Huraerah, Abu (2011). Pengorganisasian dan Pengembangan Masyarakat, Bandung: Humaniora Prijono, Onny S. dan A.M.W. Pranarka, ed. (1996). Pemberdayaan : Konsep, Kebijakan, dan Implementasi, Jakarta : CSIS

Suharto, Edi (2005). Membangun Masyarakat Memberdayakan Rakyat, Bandung : PT. Refika Aditama

Wibhawa, Raharjo dan Budiarti S (2010). Dasar-Dasar Pekerjaan Sosial, Bandung: Widya Padjadjaran

Wiranto, Tatag dan Tarigan, Antonius (2002). Artikel : Kemitraan Bagi Pengembangan Ekonomi Lokal (KPEL), : Universitas Gajah Mada 